\title{
The Cambridge Companion to MEDIEVAL ETHICS
}

Edited by

Thomas Williams

University of South Florida 


\section{CAMBRIDGE UNIVERSITY PRESS}

University Printing House, Cambridge CB2 8BS, United Kingdom

One Liberty Plaza, 20th Floor, New York, NY 10006, USA

477 Williamstown Road, Port Melbourne, VIC 3207, Australia

314-321, 3rd Floor, Plot 3, Splendor Forum, Jasola District Centre,

New Delhi - 110025, India

79 Anson Road, \#06-04/06, Singapore 079906

Cambridge University Press is part of the University of Cambridge.

It furthers the University's mission by disseminating knowledge in the pursuit of education, learning, and research at the highest international levels of excellence.

www.cambridge.org

Information on this title: www.cambridge.org/9781107167742

DOI: $10.1017 / 9781316711859$

(C) Cambridge University Press 2019

This publication is in copyright. Subject to statutory exception and to the provisions of relevant collective licensing agreements, no reproduction of any part may take place without the written permission of Cambridge University Press.

First published 2019

Printed and bound in Great Britain by Clays Ltd, Elcograf S.p.A.

A catalogue record for this publication is available from the British Library.

Library of Congress Cataloging-in-Publication Data

Names: Williams, Thomas, 1967- editor.

Title: The Cambridge companion to medieval ethics / edited by

Thomas Williams, University of South Florida.

Description: New York: Cambridge University Press, 2019. |

Series: Cambridge companions |

Includes bibliographical references and index.

Identifiers: LCCN 2018038848 | ISBN 9781107167742 (hardback) |

ISBN 9781316618110 (paperback)

Subjects: LCSH: Ethics, Medieval.

Classification: LCC BJ231.C36 2018 | DDC 170.9/02-dc23

LC record available at https://lccn.loc.gov/2018038848

ISBN 978-1-107-16774-2 Hardback

ISBN 978-1-316-61811-0 Paperback

Cambridge University Press has no responsibility for the persistence or accuracy of URLs for external or third-party internet websites referred to in this publication and does not guarantee that any content on such websites is, or will remain, accurate or appropriate. 


\section{Contents}

List of Contributors page vii

List of Abbreviations $\quad$ xi

Introduction 1

Thomas Williams

PART I HISTORY

1 From Augustine to Eriugena 9

Erik Kenyon

2 From Anselm to Albert the Great 32 Ian Wilks

3 From Thomas Aquinas to the 1350s 55 Eric W. Hagedorn

4 Islamic Ethics $\quad 77$ Jon McGinnis

5 Ethics in Medieval Jewish Philosophy 101 T. M. Rudavsky

PART II CONCEPTS AND THEMES

6 Happiness 127

Jeff Steele 
vi CONTENTS

7 Virtue

Thomas M. Osborne, Jr.

8 Law

Jean Porter

9 Freedom without Choice: Medieval Theories

of the Essence of Freedom

Tobias Hoffmann

10 Practical Reasoning

M. V. Dougherty

11 Will and Intellect

Thomas Williams

12 Emotions

Martin Pickavé

13 Medieval Christian and Islamic Mysticism and the Problem of a "Mystical Ethics"

Amber Griffioen and

Mohammad Sadegh Zahedi

14 Economic Ethics

306

Roberto Lambertini

15 Self-Interest, Self-Sacrifice, and the Common Good John Marenbon

16 Sin and Grace

Eileen C. Sweeney

Bibliography

Index 


\title{
I 3 Medieval Christian and Islamic Mysticism and the Problem of a "Mystical Ethics"
}

\author{
Amber Griffioen and \\ Mohammad Sadegh Zahedi
}

\section{3. I INTRODUCTION}

The relationship between medieval mysticism and medieval ethics is a complex one for several reasons. First, the texts and figures to which the label "mystical" has been applied are wide-ranging and diverse. They thus not surprisingly exhibit a range of attitudes toward the role of ethics and morality. Second, mysticism is often viewed as being centrally oriented around certain kinds of experiential states, which are not directly subject to the will and thus appear unlikely candidates for moral evaluation. Third, the apophatic and antinomian tendencies of some mystical traditions lend the appearance of a kind of antipathy toward positive moral prescription, leaving one to wonder whether such traditions reflect concerns that can properly be called "ethical." At the same time, discussions of goodness and perfection, virtue and vice, will and practice, abound in medieval mystical texts. Most if not all mystical traditions propose some end associated with human perfection or the achievement of what is most worthy of pursuit - one that can be achieved through the development of various habits and traits acquired through practice. Indeed, there is good reason to characterize mystical traditions as fundamentally practical, even where they are also epistemic and/or contemplative (see Hollywood 2012, 8).

In this chapter, we will explore in detail a few challenges that threaten to undermine the understanding of medieval Christian and Islamic mystical traditions as putting forward anything resembling a systematic ethics, and we will discuss how certain Christian and 
Islamic figures grapple with these issues within their respective traditions. In so doing, we will also examine the roles that love, suffering, and mystical union play in these traditions and the relevance of these phenomena for understanding the ethical import of mystical practice in medieval Christianity and Islam.

\section{3.2 TERMINOLOGICAL AND METHODOLOGICAL}

CONCERNS: MYSTICISM AND COMPARATIVE PHILOSOPHY

Before turning to the various theoretical worries concerning the question of a "mystical ethics," it is important to first address some significant terminological and methodological issues concerning how we are to understand the term "mysticism," and how investigations in the domain of "comparative philosophy" with respect to mysticism should proceed.

From a terminological standpoint, it is important to note from the outset that the labels "mysticism" and "mystical" as used in contemporary scholarship are relatively late additions to the scholarly conceptual repertoire and were not employed by the medieval persons under discussion here to describe themselves (see Hollywood 2012, 5; Van Dyke 2010). Moreover, the application of these terms in contemporary Western philosophical scholarship has often served to (further) marginalize and exclude certain figures and traditions from the realm of "serious" philosophical investigation. Indeed, the common coupling of "mysticism" with modifiers like "esoteric," "unsophisticated," or "unsystematic" often betrays certain widespread philosophical biases against historical thinkers who write for (or as) members of gender and social minorities, or who tend, for example, to emphasize the affective and experiential over the cognitive and speculative, to express themselves in the vernacular as opposed to the language of scholars, or to utilize literary forms of expression that depart from traditional scholastic genres. ${ }^{1}$

Still, the question remains as to what we should understand by the term "mysticism," especially as concerns comparative undertakings between Christianity and Islam. While remaining 
aware that the term may serve various functions in the scholarly literature, in what follows we will adapt and extend Christina Van Dyke's working definition of late Christian mysticism for our own comparative purposes by understanding a "mystical tradition" most generally as a series of teachings and practices embedded within a particular religious context that are aimed at both understanding and achieving the appropriate relationship of the human to the divine in this life, where this relationship is assumed to go "beyond the realm of normal earthly experience" and to represent "the ultimate fulfillment of human nature." ${ }^{2}$ This approach incorporates both the epistemic and practical aspects of mysticism, while also allowing it to take apophatic or affective, contemplative or performative, discursive or lyrical forms to greater and lesser degrees.

Additionally important for our purposes is the fact that mystical texts generally serve an essentially didactic or "mystagogical" function (see Bruijn 1997; Haas 1989, 34ff.). They aim to cultivate and impart behavior-guiding knowledge, whether via explicit instruction, the presentation of exemplars, the crafting of allegories, or some other means. Such texts are not mere "esoteric expressions" of affect or experience and thus should not, indeed cannot, be neatly divorced from their theoretical and practical philosophical and theological underpinnings. In this sense, then, although the term "mystical" is often employed to sideline or dismiss certain figures and texts as irrelevant to the philosophical tradition, we think that mysticism is rife with fodder for philosophical exploration.

However, even with this general understanding of mysticism at our disposal, a methodological worry arises regarding how one is to productively undertake comparative research on mysticism. On the one hand, one must be wary of over-essentializing mystical traditions, reducing them implausibly to some basic experiential or theoretical core, while glossing over relevant cultural, historical, and religious differences. On the other hand, one must be careful not to over-particularize such traditions to the point that there is nothing 
left to compare. Thus, while we agree it is bad practice to try to reduce the voluminous works of, say, ibn 'Arabi and Meister Eckhart to some more "basic" form of mysticism common to both of them, we also think that there can be fruitful points of resonance between mystical traditions, especially when seeking illumination on a particular scholarly question or issue. We therefore intend to follow Saeed Zarrabi-Zadeh $(2014,290)$ in viewing the particular texts and ideas to be compared here as "'mirrors' reflecting and revealing various facets of one another," such that "comparison becomes a tool of clarification and comprehension rather than of assimilation or differentiation."

In what follows, then, we intend to set the ideas of particular Christian and Islamic mystical thinkers side by side to shed some light on the question of whether the category of "medieval mystical ethics" can be a theoretically fruitful one. Indeed, although much mystical literature is intended to provide instruction, edification, and practical guidance on the mystical path to right relationship with God, such texts rarely spell out a comprehensive ethical system, especially in cases in which mystagogical education is supplied through allegory or poetic metaphor. This less discursive aspect of mysticism raises the question of whether the ethical themes in these traditions are conducive to systematization along the lines of normative ethical theory. We will thus raise some theoretical concerns for the formulation of a coherent "mystical ethics" within such traditions and discuss a few ways in which particular medieval Christian and Islamic mystics grappled with these or related concerns. While we understand that many of the ideas we will use in raising these worries stem from contemporary moral theory and are thus perhaps anachronistic when applied to medieval mysticism, this fact only serves to sharpen the tensions between medieval mystical traditions and normative ethics. Do such traditions provide us with something that we could recognize today as an ethical theory? Or should we find another way to talk about the practical and normative aspects of medieval mysticism? 


\section{3 .3 THEORETICAL CONCERNS I: DO MYSTICAL} TRADITIONS PROVIDE A COHERENT THEORY OF VALUE?

"How can one imaginatively construct [gebilden] that which is imageless [bildlos] or methodically demonstrate [bewisen] without methods [wiselos] that which is beyond all the senses and human reason? For whichever simile [glichnust] one selects, it is a thousand times more dissimilar [ungelicher] than similar [glich]. ${ }^{\prime 3}$ Here, in a lovely bit of Middle-High-German wordplay, Heinrich Seuse (d. 1366), also known as Henry Suso, responds to the request of his "spiritual daughter," Elsbeth Stagel (d. 1360), for a more comprehensible summary of the divine nature. The apophatic tendency Suso displays here is one that runs through many medieval Christian mystical traditions and stems in a large part from the fifth- to sixthcentury Dionysian corpus (which itself draws heavily on the works of the classical Neoplatonists). On this approach, the divine is wholly transcendent and beyond all limitation, including that of being discursively knowable or describable through language. (For more on the challenges posed by Pseudo-Dionysius, see Erik Kenyon in this volume, 1.4.)

The mystical Sufi corpus, too, draws heavily on Neoplatonic sources in emphasizing the unknowability and indescribability of the divine. Ibn 'Arabi (d. 1240), for example, claims that the divine never discloses itself as it is in its essence, since the latter is, given its absolute illimitability, unknowable by the necessarily limited human intellect, which comes to know things precisely by demarcating ("de-limiting") them: "We have nothing of knowledge other than attributes of declaring incomparability and attributes of acts," he writes. "He who supposes that he possesses knowledge of a positive attribute of [God] has supposed wrongly, for such attributes would limit him, while his Essence has no limits." ${ }^{4}$

There are at least two related theological reasons for the apophatic tendency in these traditions. From a metaphysical standpoint, placing God beyond all delimitation or conceptualization ensures the 
radical ontological distinction between creator and creature, thereby affirming the utter transcendence and non-imperfection of the divine. From a moral standpoint, it protects human beings from the sin of idolatry by asserting that, strictly speaking, nothing can be properly thought, said, or (discursively) known of the divine construed in such a way.

Nevertheless, from the standpoint of ethical theory, we might be left to wonder whether the apophatic approach is capable of providing a coherent theory of value that could form the basis for a normative mystical ethics. Most straightforwardly, it would seem that the ultimate "object" of value (or, what turns out to be the same, the illimitable source and expression of all value itself) is not the kind of "thing" that can be an object of theorizing at all, for even to say that God is the "Ultimate Good" is to predicate something of the divine that, strictly speaking, cannot be legitimately predicated of it. Of course, we might think that if we restrict our theorizing about value to outlining the ultimate good or goal for human beings in this life, we can actually say something positive about the good life in a way that would provide us with a satisfactory theory of value for a mystical ethics. But even here, assuming as we have that mystical traditions represent the ultimate good for human beings as involving uniting with, being annihilated in, or otherwise entering into some particular relationship with the divine, it would seem that one relatum of the relevant theoretical relation remains necessarily inaccessible to human reasoning or systematization, leaving any potential theory of value unfortunately incomplete.

\section{I3.4 TO "SEE THE WORLD ARIGHT": CLIMBING THE APOPHATIC LADDER}

Yet perhaps we should not be too hasty to jettison all talk of value even ultimate value - in apophatic medieval mysticism. To begin, not every mystical tradition adopts such a radically apophatic approach to the divine. For example, many thirteenth- and fourteenth-century female Christian mystics in the Beguine tradition were remarkably 
cataphatic. Further, many mystical authors relied on the very tension between the apophatic and cataphatic to bring their mystagogical ideas to expression. Indeed, the fact that even the figures discussed above persisted in attempting to describe, illustrate, or otherwise express the reality of the divine and the individual's path to relation with it demonstrates their commitment to the idea that such an endeavor is a crucial component in the pursuit of the highest end. At the same time, the requirement in both Christian and Islamic apophatic traditions that, as part of this journey, the soul radically "de-image" itself and rid itself of its attachment to illusory and idolatrous conceptions of God still seems to stand in tension with the positive assertion of God-qua-ultimate-value, especially on the assumption that any positive conception of the divine whatsoever is necessarily idolatrous.

The dominant position here seems to be the idea that what cannot be said can nevertheless be "shown" - or at least gestured at. For example, in the passage immediately following Suso's retort to Stagel quoted above, instead of falling into apophatic silence, the Dominican continues with his wordplay: "But listen, in order to exorcise the image [bild] through imagery [mit bilden], I want to show you figuratively [biltlich] with figurative [gleichnusgebender] speech as far as it is possible - these same imageless meanings [bildlosen sinnen] as they are to be taken in truth and close a long speech with short words. ${ }^{\prime 5}$ Elsbeth is then asked to imagine the ripples on a pond into which a stone has been forcefully thrown as the effect of the "unfathomable" power of the "deep abyss" that is the Godhead as it flows out into creation, as Suso describes the Neoplatonic ontological exitus in great lyrical detail. In increasingly concrete and visual terms, he then lays out step by step the path by which the soul undertakes its affective and epistemic reditus back to God through Christ. Indeed, it is likely that Suso himself employed visual imagery, both in his own devotional practices and in his instruction of female nuns, and that he commissioned a variety of illustrations to accompany his written works, indicating the contemplative and didactic 
potential he saw in such imagery. ${ }^{6}$ Similar pedagogical ideas come to expression in the Sufi poet Rumi (d. 1273), who - despite claiming that outward "form" and appearance are impediments to reality wrote volumes of parables and fables rich with imagery, advising his readers that "Although its inner meaning is the bait, / First listen to this story's form, then wait" (Rumi 2008, [2635]). Ultimately, however, the goal is to leave such images behind: "You worship idols when fixed in form's realm, / Leave form behind, find meaning inside them!" (Rumi 2008, [2906]).

Suso's discussion of exorcising images through imagery, and Rumi's insistence on arriving at inner meaning by paying close attention to outer form, point us to one way in which apophatic medieval mystics may have grappled productively with the tension inherent in positing an ultimate value that cannot be appropriately expressed. Images and metaphors are employed as a means for making spiritual progress, one which initially serves an edifying and illustrative purpose, but which finally culminates in an understanding of their ultimate meaninglessness. In other words, images for these mystics are akin to a kind of "Wittgensteinian ladder" that must be thrown away after one has climbed up on it (see Wittgenstein 2005, $\S 6.54)$.

Thus, if viewed as a quasi-eudaimonistic ethics aimed at elucidating the pursuit of the ideal telos for the human individual, apophatic mysticism can provide a theory of value - namely, right relationship with the divine - but insofar as it remains a discursive theory involving some characterization of what is finally ineffable, such a theory can only serve an initial heuristic or guiding function. Ultimately, it itself must be discarded as a theory. To really be in relationship with God is to have moved beyond the idea of God as the upper bound in some definable value function. It involves, as Michael Sells notes in his discussion of ibn 'Arabi's apophaticism, "a perspective shift ... through which normal reference, predication, logic, metaphor, and myth narration are transformed into the language of realization, manifestation" (Sells 1988, 134). 
Importantly, the apophatic doctrine itself plays an ineliminable practical role in this transformation. As Sameer Yadav has aptly demonstrated, doctrines of divine ineffability serve an essential function in ordering individuals to their proper end: not only do they set out "the sense in which we can and cannot get God right in theology," they also provide "a normative practical guide to spiritually unite us with God by way of our successful and failed attempts to get God right."7 This "practical apophaticism" can, for instance, assist the spiritual traveler in struggling with the challenge of divine hiddenness as she makes progress on her mystical journey. The Sufi emphasis on speaking of God as a "hidden treasure," ${ }^{\prime 8}$ the poetic laments of Attar (d. 1220) and Hafez (d. 1389) about the lost Beloved, the Dark Night of the Soul traditions of Teresa of Avila (d. 1582) and John of the Cross (d. 1591), the fifteenth-century Upper Rhineland depictions of Christ hiding behind a curtain from his love-inflamed bride ${ }^{9}$ - all these illustrious expressions of divine inaccessibility serve to remind mystical wayfarers that, while they may have made progress on their spiritual journey, they have not yet reached their goal.

In this vein, Marguerite Porete (d. 1310) writes in her Mirror of Simple Souls that the "sad souls" who have achieved a kind of second-order understanding of their own ignorance with respect to the divine are wiser and more praiseworthy than their ignorant counterparts: "they understand well that they do not have understanding of this better thing which they believe" (Porete 1993, $\S 57$.$) Likewise, Ebrahim Azadegan points out that the sense of divine$ hiddenness awakened by such conceptual failures may serve as a kind of invitation to continue the apophatic struggle as one seeks the "hidden treasure" that is God (see Azadegan 2015). Or, as John of the Cross (1994) advises, they might indicate that one should give oneself over completely to trust in God and quiet inactivity in which the soul is left "free and disencumbered and at rest from all knowledge and thought ... with merely a peaceful and loving attentiveness toward God." 
Yet this latter "call to inaction" points to a further worry regarding the possibility of formulating a coherent mystical ethics namely, whether medieval mystical traditions can really provide an adequate theory of right action, let alone be action-guiding, especially given their unique virtue-theoretic approaches and the tendency in some traditions toward antinomianism, passivity, and the loss of self. It is to a discussion of these issues that we now turn.

\section{3.5 THEORETICAL CONCERNS II: DO MYSTICAL} TRADITIONS PROVIDE A COHERENT THEORY OF RIGHT ACTION?

The large majority of the mystical traditions under discussion here are situated within a virtue-theoretic framework, and Sufism is no exception. In many Sufi traditions, the connection between virtuousness and making progress on the mystical path is so tight some have claimed that there is no real distinction between ethics and Sufism (see Kashani 1992, 174). In this vein, Abu-Nasr al-Sarraj (d. 988) cites Junayd of Baghdad (d. 910) as answering the question "What is Sufism?" by claiming that "Sufism is good morals possessed at a good time by a good person in the company of other good people." ${ }^{10}$ At the same time, even if it is not entirely incorrect to say that all stations on the Sufi mystical path display some moral concern or other, the achievement of moral excellence itself is often taken to represent merely the first stage in the individual's spiritual growth, namely that of the so-called "journey from the world to the Truth,"11 in which the soul is freed from attachment to the world and "breaks through" to experiential annihilation in God. It is here that the development of moral character is most emphasized.

This stage is one of immense difficulty: Sufis point to nafs, or the "carnal soul," as the inner "enemy" that represents the main obstacle to embarking upon the spiritual journey. Combating and breaking away from the creaturely and carnal desires of nafs is necessary to achieve transcendence, and this struggle represents the core of Sufi ethics. ${ }^{12}$ Here, moral progress proceeds according 
to two closely intertwined phases: first, the struggle to cleanse the soul of vice and, second, the effort of obtaining certain virtues. Rumi likens vice to a mouse that has made a hole in the grain sack of the soul: any good feature of character obtained will continue to spill out of it unless the mouse is dealt with and the hole patched. He thus advises, "Defend against the mouse first, that's the plan / Then come and gather all the wheat you can!" (Rumi 2008, [381]). On this and similar approaches, the more one is freed of vice and evil and adorned with virtue and merit, the closer one comes to the divine - in the sense both of approaching God and of mirroring or imaging the divine nature through virtuous action. Among the most important vices to be purged are pride, envy, and hypocrisy. From here, the virtues are acquired in stages, each of which builds upon those prior to it. While the order and number of these stages differ among various mystics, almost all Sufi thinkers are in agreement that the highest virtue and/ or the aim of all other virtues is that which creates the possibility of intimate proximity to and/or genuine annihilation in the divine, namely love (see Chittick 2014).

A similar emphasis on the preparatory purgation of vice and the soul-building acquisition of virtue in the service of love can be found in various Christian mystical traditions. Indeed, the emphasis on unitive love as the sum or culmination of all virtue is found throughout the Middle Ages in the Christian world, especially in those traditions of "bridal" and "love" mysticism, as exemplified by Bernard of Clairvaux (d. 1153), the thirteenth- and fourteenthcentury Beguines, Henry Suso, Catherine of Siena (d. 1380), Julian of Norwich (d. 1416), and many others (see, e.g., Dickens 2009). A particularly striking example is found in the devotional image-and-verse program, Christ and the Loving Soul, which was popular in the Upper Rhineland in the fourteenth to sixteenth centuries. Here, the soul, represented as the sponsa Christi (bride of Christ), is depicted (both visually and in rhyme) as being violently beaten, blinded, lamed, stripped, and ultimately hanged by her heavenly bridegroom. ${ }^{13}$ This brutal (and admittedly quite misogynistic) allegorical 
scene, however, represents the initial "purgation" of vicious bodily attachment to the world that serves to activate the soul's "inner" (spiritual) senses, allowing her not only to pursue the acquisition of "virtue great and small" but ultimately to actively seek out genuinely loving union with her bridegroom (which she does by hunting him down and wounding him with her "arrow of love" $).{ }^{14}$

Thus, in both Christian and Islamic mystical traditions a central pattern emerges according to which the acquisition of virtue goes hand in hand with the spiritual wayfarer's making a spiritual movement from the outer to the inner. The completion of this movement results in a radical affective and volitional shift involving a loss of the selfish, worldly ego and the first steps toward attainment of a closeness to the divine manifested in love and wisdom. However, it is also here that medieval Christian and Islamic traditions encounter a first difficulty when it comes to providing anything resembling a systematic theory of right action. Although the acquisition of moral virtue is necessary for the subjective turn inward, there is a sense in many of these traditions in which the achievement of genuine proximity or union with the divine requires moving beyond common morality in some relevant way, such that the religious and moral laws - as well as the virtues and vices associated with these laws - no longer apply in the way they did before. For this reason, such traditions have often come under fire for supposedly promoting various kinds of antinomianism regarding moral action.

Marguerite Porete (who was subsequently burned at the stake for heresy), for example, notes that the soul who has acquired the virtues in the service of reason and lives her life in service to God and neighbor at some point "considers that God counsels His special lovers to go beyond what He commands" (Porete 1993, §118). She understands that spiritual progress demands that she sacrifice that which is now most dear to her, namely her love of good works, and thus takes leave of the virtues to whose constancy she was a "slave" (Porete 1993, §6). Meister Eckhart, upon whom Porete's writings likely exercised some influence (see McGinn, 1994, 2001, 9), makes 
similar claims: "You should traverse and transcend all the virtues," he writes, "drawing virtue solely from its source in that ground where it is one with the divine nature" (Meister Eckhart 2009, 117). He even goes so far as to claim that "Whatever a man's vows to manifold things, by entering into true inwardness he is released from them" - a shocking statement for a fourteenth-century Dominican friar (Meister Eckhart 2009, 52-53.)

Many Sufi mystics were also historically accused of heresy by their contemporaries for endorsing and practicing various kinds of antinomian policies, which were seen to violate the divinely ordained commands of sharī'a law (see Karamustafa 2015). In the section of his Book of Flashes titled "On those who erred in fundamentals and were led to misbelieve," al-Sarraj lists several types of such "heretical" antinomians (see Renard 2009, 54). Yet such positions were not just occupied by "fringe" sects of Sufism. Rumi famously dedicated one of his most celebrated works, the Divan, to his beloved antinomian qalandar (or "wandering dervish"), Shams-i Tabrizi (see Nasr 2007, 294.). He also commonly avails himself of what Leonard Lewisohn $(2015,78)$ calls a "poetic symbolism drawn from a bacchanalian lexicon couched in an antinomian Sufi tavern slang," employing metaphors of wine and drunkenness to describe the ecstasy of the mystic. Yet even apart from his reliance on images of intoxication, Rumi also makes some surprising statements in a few more "welltempered" passages of the Masnavi. In his tale of the Old Harpist, he writes: "Why still repent about a state that's passed? / Repent of your repentance now at last!" (Rumi 2008, [1717-1720]). And in speaking of the fresh, hidden "waters" of God's unseen wisdom, he seems to claim that the very categories of virtue and vice are tied up with our fundamental ignorance of the divine nature: "If such rains that are hidden should increase / Both vice and virtue in this world would cease" (Rumi 2008, [2082-2083]).

It therefore appears that any normative ethical system embedded in such Christian and Islamic mystical traditions is going to encounter serious difficulty in providing a satisfactory account of 
right action, insofar as the mystic who has acquired the basic moral virtues must necessarily transcend the stage according to which action is understood as right or wrong, morally required or forbidden, permissible or impermissible. At the same time, many of these traditions place an alternative set of "mystical virtues" at the very center of their accounts - dispositions of character which are thought to either lead to or exemplify the ideal mystical attitude. However, these mystical virtues correspond less to the traditional Aristotelian "doctrine of the mean," occupying a temperate "middle ground" between two moral excesses. Rather, they tend to locate themselves at the extreme negative end of the relevant continuum, one essentially characterized by the ideal of utter passivity on the part of the mystically virtuous subject. Indeed, the goal of complete and total submission to God lies behind many of the mystical virtues extolled by Christian and Islamic mystics and, as we shall see, represents another challenge to the idea that a "mystical ethics" can provide an adequate theory of right action.

One such "negative virtue" emphasized by mystics in both traditions is that of total humility, a virtue without which it is impossible to be united to God, whether the relevant union take the form of total annihilation or a relation of intimate proximity culminating in mutual love. Teresa of Avila, for example, claims that genuine humility is that which requires no volitional effort on the part of the individual and "which causes an embarrassment that undoes one." It is common knowledge, she writes, "that God gives a knowledge that makes us realize we have no good of ourselves; and the greater the favors, the greater is this knowledge" (Teresa of Avila 1976, 146). The significance of this kind of humility is not to be overlooked, since it has interlinked moral and epistemic aspects. As Nasr (2007, 126) notes, in the Sufi context "humility is not simply the sentimental attitude of humbling our egos before God and the neighbor. It is the metaphysical awareness that before the Absolute we are nothing." This metaphysical awareness of its absolute nothingness in the face of the divine primes the penitent soul for the ultimate 
affective and volitional purgation of self-love and prideful willfulness and prepares it to be filled with divine grace.

Meister Eckhart and Henry Suso, for their part, place abgescheidenheit ("detachment") and gelâzenheit ("serenity," "releasement") at the center of the mystical life. For Eckhart, detachment represents the highest mystical virtue to which one can attain in this life, higher even than the virtues of love, humility, or compassion..$^{15}$ Whereas the latter virtues may still "constrain" the agent volitionally in some way, true detachment makes one wholly unconstrained and responsive to God. Yet such detachment is characterized, not by virtuous activity, but by total receptivity: the soul cannot be attached to anything whatsoever or have any objects that might improperly occupy it with anything other than God. It is, in some sense, fully sufficient in its pure potentiality. In Suso, on the other hand, it is gelâzenheit or "releasement" that receives the most attention. Those who see the outward but not the inward aspect of things may live "strict" and "scrupulous" lives, but they overlook the inner aspect that requires "taking leave of the self," "losing grasp of one's nature," and "the loss of the things that preserve and protect the will." Only in this state of "having-let-go" can one come to the genuine negative virtues of "obedience, compliance, tolerance, and the like." ${ }^{\prime 16}$

In all these cases, genuine mystical virtue is only possible from the perspective of a subject who has given herself over to that with respect to which she experiences her own impotence and dependence, namely to the divine. Certainly such virtue can be developed or cultivated, e.g. by engaging in practices of asceticism or self-denial, but - like the Wittgensteinian ladder of the previous section - these practices, too, as operations of the individual will, must ultimately be left behind. ${ }^{17}$ Thus, for example, in Mechthild von Magdeburg's (d. 1282) Flowing Light of the Godhead, the soul initially clothes herself in the "holy cloak of good reputation," which is "gilded with all the virtues," only to be later told by Christ that she must disrobe and "cast off all outward virtues." The soul then stands "naked" before 
her Beloved, allowing a "blessed silence" to enter between them that both desire. ${ }^{18}$

What the mystical life ultimately demands, then, is not action but rather inaction - or, perhaps better put, an absence of action. Genuine mystical virtue is exemplified, not by a habituated disposition toward certain kinds of acts or omissions, but rather by an overarching disposition not to act at all. The question concerning a "mystical ethics" thus becomes not merely whether some mystical traditions recommend an antinomian move beyond actions understood as right or wrong, but whether they can provide any theory of action at all, at least once the mystical wayfarer has reached this stage on her journey.

This worry becomes even more troublesome when we consider that not only is the truly exemplary life of the mystic characterized by stillness and non-action, but that many of these quietistic traditions actually endorse a loss of the ethical subject altogether. Thus, Abu Sa'id al-Kharraz (d. c. 895) is reported to have claimed that "the servant" befriended by God, who is lifted up to "the assemblies of Intimacy" and set "on the throne of Oneness," "remains without [individual] inclination," becoming "chronically lost [in God]" and wholly "free from the claims of his self." ${ }^{19}$ Likewise, the poet Hafez writes, "No path can be taken, unless you see yourself not." ${ }^{20}$ But if this is right, and one must become wholly devoid of egocentric interest and desire, completely detached from self and world, and passive even to the point of relinquishing one's own identity, it appears to be not only the case that one cannot act morally but rather that there is no subject, deliberator, or agent left who could effectively act at all, let alone act for practical or moral reasons.

Nonetheless, we maintain that if we take these three related worries (concerning antinomianism, passivity, and loss of agency) together, what emerges is not best understood as non- or even trans-ethical. After all, such forms of mysticism do provide a comprehensive picture of the Good Life and the fulfillment of human nature - one which admittedly goes beyond morality in a restricted 
sense, yet which nevertheless provides a view of the ultimate telos of human beings and which strongly endorses two further values embraced by contemporary moral theory, namely freedom and autonomy, though in a sense perhaps somewhat foreign to modern thought. To see how this is so, it will be instructive to examine more closely the work that the negative virtues are doing in this system and how the practice and acquisition of such virtues are supposed to lead - not to unlawful behavior, apathetic inactivity, or total loss of self - but paradoxically to a kind of self-actualization that results in genuinely free, autonomous, hypernomian action.

\section{3.6 "BECOMING WHAT ONE IS": SUFFERING, FULFILLMENT, AND SELF-ACTUALIZATION}

Given what we have said above, it should come as no surprise that suffering plays an important role in medieval mystical contexts. Although a common criticism of many medieval mystics is that they appear to endorse a perverted glorification of asceticism and self-mortification, such criticisms fail to appreciate the complex function that suffering serves in mystical thought. First, suffering is a universal phenomenon - an inescapable part of our existential condition, as it were. Second, it is not something we do but rather something we undergo, and thus involves a kind of passivity that lends itself well to mystical discourse concerning the acquisition of the negative virtues we have mentioned above. Finally, suffering often has a dramatic effect on us in ways that can serve to shape, alter, or even transform our wills, whether for better or for worse. Together, these three aspects of suffering - its universality, its passivity, and its transformative power - can help explain why it plays such a significant role in many Christian and Islamic mystical traditions and why it is relevant for our discussion of mystical ethics.

Returning to Suso may be instructive here. Although he recommends that the mystical wayfarer become entbildet ("deimaged" or "un-formed") through the kinds of apophatic practices discussed above, this is only the beginning of the mystical journey. 
Suso maintains that two further stages are necessary for human fulfillment, namely becoming gebildet, or "[re-]formed," through Christ and ultimately úberbildet, or "trans-formed," in the Godhead. ${ }^{21}$ Whereas the stage of un-formation corresponds roughly to the virtue of detachment extolled by Eckhart, for Suso being re-formed through Christ occurs through the acquisition of the aforementioned virtue of releasement, which is itself best attained, he maintains, by learning to suffer: in a vision, Christ instructs "the Servant" (Suso), first, to "receive suffering willingly," second, to "bear suffering patiently," and third, to "learn to suffer in the manner of Christ." 22 For Suso, suffering is universal both insofar as we all necessarily experience it in some form or other and insofar as it represents the means by which embodied human creatures participate in the life of the Incarnate God, whose passion and death represent the ultimate expression of divine love. The three steps of "learning to suffer" move the individual progressively from activity to passivity via a process of "unbecoming" - of "letting go." While suffering can be received willingly, one is ultimately passive with respect to its effects. Yet in practicing the patient toleration of suffering, Suso thinks, one puts oneself in a better position to suffer in the manner of Christ, who is the ultimate exemplar of negative virtuosity. In "learning" how to suffer, then, the subject learns not only how to patiently imitate Christ's moral example (imitatio) but also to realize that, as the imago Dei, she also suffers with Christ (compassio). This kenotic "emptying" of the soul by learning to suffer is thus part and parcel of what it is to become formed in Christ, and it is only via such an emptying that the soul can be truly fulfilled - "trans-formed" - in the love of divine union.

Suffering also plays a significant role in Rumi's thought. Here, suffering is symptomatic of the immense gulf between all creatures and the divine, and of the longing every soul experiences to return to its origin: "When kept from their true origin, all yearn / For union on the day they can return" (Rumi 2008, [1-4]). As the individual makes spiritual progress, then, and comes to realize her true nature, her awareness of the distance between her and the divine increases 
and thus leads to a more intense sense of suffering: "That being sick can heal you thus makes sense, / It wakes you with increased intelligence! ... The more awake they are the worse their plight, / Their suffering turns their tortured faces white!" (Rumi 2008, [628, 631633]). Yet unlike illusory suffering, which often stems from improper attachments to self and the world, this "tortured," reflective suffering is authentic - it stems from a genuine (and correctly perceived) ontological and epistemic divide with respect to which the subject is completely passive. And, as with Suso, it is also therapeutic, insofar as the suffering engendered by enlightened love serves a transformative soul-building function. In this sense, the disease can be a source of its own cure.

The instrumental value of suffering and self-emptying in these traditions can clue us in to the roles that action and agency play in the service of the negative virtues. First, the acquisition of the virtues of humility, detachment, releasement, and the like requires a significant degree of practice on the part of the soul, and this is something that does involve activity of the will. One engages in activities that have as their end an "emptying" of the intentional objects that can occupy the soul and distract it from the proper object of its love, namely the divine. Here, following the religious laws of Christianity or Islam represents the first stage of "impoverishing" the soul in this manner. Yet to truly become prepared for being filled with divine love, one must move beyond blind rule-following, for to perform actions by the movements of one's individual will is still to be bound by the strictures of the moral law and the confines of prudence - to be a "slave" to reason and virtue, as Porete would put it. Thus, one must be given over to suffering as a patient rather than insisting on willing as an agent.

Indeed, there is a very real sense in these traditions that the self qua individual moral agent is never fully free. She may "pseudo-autonomously" will the moral law for herself, but genuine autonomy - and true freedom - can only be exercised by God, the freely giving divine legislator. Therefore, to experience this kind of 
autonomy, the human individual must give herself over to God completely - to "suffer" God, as it were. She becomes a vessel for the divine, who may be rightfully said to "fill" and "complete" her - to actualize her by working through her. In this sense, willful human "action" properly aims at giving way to overriding divine acts of grace, which in turn serve to perfect the individual's deficient human nature, thereby conferring genuine agency upon her in and through divine love.

When we view the mystical journey as one of self-actualization through alignment with the divine will, we can see why Sufi mystics have traditionally been so fond of the Qur'anic verse that "you [Muhammad] threw not when you threw, but it was Allah who threw" (Surah Al-Anfal 8:17). Here, theological occasionalism takes on mystical significance by expressing the idea that all action, properly understood, is divine action. The enlightened soul who has been "annihilated" in God is in a special position to understand and accept that his actions are only really his in the sense that they flow from the divine will. Thus, Rumi writes: "When we fire arrows don't give us the blame - / We're just the bow, it's God who's taking aim!" (Rumi 2008, [619-20]). Yet Rumi does not resign himself dejectedly to fatalism. Since human action is an expression of the alignment of the soul with God's designs, freedom and necessity are two sides of the same coin. When we shift our perspective from our own wills to God's in humility, we see our actions as manifestations of God's power, not as the result of unfree coercion: "Don't dwell on our compulsion, but His might, / To know humility keep this in sight" (Rumi 2008, [621]). Indeed, for Rumi, freedom appears to be a largely negative notion: we only feel unfree when our wills stubbornly and egotistically resist the divine will, yet where our wills are aligned we experience no compulsion.

In this sense, these mystical authors and texts do not, strictly speaking, endorse the loss of the ethical self but rather see themselves as promoting the attainment of genuine self-fulfillment. It involves a cognitive, affective, and volitional shift away from the self sinfully 
and idolatrously understood as a wholly self-sufficient entity - as a causa sui in its own right - and toward the divine will. This may occur through the acquisition and practice of virtuous suffering, which ultimately allows the soul to "empty itself" or "forget itself" in the sea of divine love. The ultimate resignation of the will to the divine, then, results in the actualization and perfection of the individual by transforming it into the kind of thing through and/or with which the genuine (and uniquely singular) causa sui exercises its divine will.

\section{3.7 "IN BUt NOT OF THE WORLD": THE JOURNEY BACK}

However, we cannot forget that for medieval Christian and Islamic mystical traditions as we have characterized them here, namely as involving coming to both understand and achieve the appropriate relationship of the human to the divine in this life, the spiritual journey does not end with unitive experience. So long as the soul remains attached to a body, she cannot escape the world. And although some mystics recommend a hermitic life of voluntary seclusion, for many others spiritual enlightenment involves a return to a divinely pre-ordained social and embodied existence. Indeed, the mystic may ultimately acquire a further duty to instruct beginners in the mystical path - either by virtuous exemplification or as a kind of spiritual "master." In this sense, the turn from outer to inner is followed by a social turn back outward, but this time from a wholly different perspective.

In a sermon on Luke 10, Eckhart underscores this idea via a unique interpretation of the story of Mary and Martha. Here, Eckhart rather surprisingly interprets Martha's busied activity and her irritation at Mary's contemplative ardor for Christ as an indication of her spiritual superiority to her sister. He interprets Martha's plea to Christ that he bid Mary help her as a well-intentioned expression of her concern that the latter's affective devotion to Christ is more for her own sake than for his. Martha, Eckhart claims, is concerned 
that Mary might become "stuck" in the pleasurable feelings brought about by Christ's company and thereby fail to make further spiritual progress - progress she herself, through life experience, has already made. Eckhart goes on to note that while mystical experience allows one to know oneself together with God, embodied existence with others allows us to know ourselves as we are apart from God, making us aware of distinctions - including distinctions in virtue - that cannot be made when one is focusing on unity over separation, on proximity over distance. Eckhart goes so far as to say that the "pagan masters," by practicing the virtues, came to "such profound discernment that they recognized the nature of each virtue more clearly than Paul or any saint in his first rapture" (see Meister Eckhart 2009, 84). It is this wisdom that Martha has achieved, transcended, and then come (back) to embody. What makes Martha so praiseworthy for Eckhart is her "continuous state of non-absorptive union with God" - a habituated detachment that is nevertheless both necessarily active and inherently worldly. This enables her "to enjoy union with God and identify with the divine in the ground, while she lives in the world and permanently brings her inwardness and inner virtue into practice" (Zarrabi-Zadeh 2016, 27).

Thus, like Aristotelian eudaimonia, the highest good for the mystic is, in some sense, an activity - or, perhaps better put, a way of life. Whereas the acquisition of virtue is initially cultivated for instrumental reasons related to making spiritual progress, the Good Life involves virtue performed in concurrence with the divine will. Thus, whereas the virtuous agent pre-union strives to do God's will herself, the virtuous agent post-union represents both an exemplar and expression of that divine will. And insofar as being acted through (or with) is distinct from merely being acted on, the individual here is not a mere passive subject: she is an agent who acts freely in the world-more freely, according to these traditions, than those "pseudoagents" who remain sinfully attached to their own wills.

This also provides us with a possible answer to our initial worry concerning antinomianism: the mystical journey, properly 
understood, is not an antinomian enterprise but rather, as Paul Heck $(2006,256,274)$ suggests with respect to Sufism, a hypernomian one. It is a "force for surpassing, without abandoning, legal rulings," in which "abandonment of self does not lead to moral apathy or withdrawal from society but constitutes the condition for a truly moral relation with others without interest in personal comfort or gain or demand for reciprocation." Or, as Peter J. Awn $(1983,247)$ suggests, although the Sufi occupies a "different plane of existence, above the legal structures (shari'ah) and institutions that specify for the majority of Muslims the path of righteousness," it is ultimately "the relationship of lover-Beloved [human-divine] that specifies right action for the mystic, not the shari'ah-based structures delineating Islamic praxis." This corresponds to the way in which, for Marguerite Porete, although the soul must take leave of the virtues to be unified with and annihilated in the divine, this soul nevertheless "gives to Nature all that is necessary, without remorse of conscience. But such nature is so well ordered through the transformation by unity of Love, to whom the will of this Soul is conjoined, that nature demands nothing which is prohibited" (Porete 1993, §9). The annihilated soul, although radically free, will not but act as virtue would dictate. Yet she acts, not as a "slave" to virtue, but in a way in which the virtues now serve her.

\section{3.8 CONCLUDING REMARKS}

Although medieval Christian and Islamic mysticism offers accounts of the spiritual life that initially appear to be in tension with contemporary understandings of what a normative ethical theory should provide, it is not clear that the project of providing a coherent "mystical ethics" is a hopeless one. Mystical writings have often been marginalized in discussions of ethics - and of practical philosophy in general - yet the traditions in which these texts arise are, at their very core, inherently practical. Their detailed depictions of moral and religious exemplars and their complex picture of the Good Life aim to instruct spiritual beginners on a path to right relationship with 
and in the divine. Indeed, in contrast to the strands of medieval theology and philosophy conventionally described as more "scholastic" and "systematic," these mystical traditions are much more intimately bound up with individual and social practice and are ultimately inseparable from the particular ways of life that both ground and are shaped by them. While the "solutions" we have proposed to the problems in providing a sufficient theory of value and an adequate theory of right action might not satisfy the demands of many contemporary ethical theorists, we hope to have at least shown that the Christian and Islamic mystical authors under discussion here weave nuanced understandings of the ultimate end of human existence into a complex theological and religious tapestry in fascinating ways that demand further philosophical exploration. ${ }^{23}$

\section{NOTES}

I Thus, for example, many female Christian mystics employed and extended sophisticated theological and philosophical tropes in creative ways that exercised influence on their male peers, yet most wrote in the vernacular, often using poetry or allegory to convey their thoughts, and the relegation of their work to the "mystical" domain has largely functioned to diminish their intellectual and historical significance. For various treatments of the intellectual erudition and influence of female mysticism, see, e.g., Bynum I994, Dickens 2009, Keller 2000, McGinn I994, Van Dyke 2016.

2 See Van Dyke 20io, 722. We depart from Van Dyke insofar as we do not insist that "the ultimate fulfillment of human nature" always be a matter of union with the divine, nor that it always be direct or immediate. If, for example, a mere "close proximity" to the divine is the most we can achieve in this life, as some Sufi thinkers maintain, then direct union might be, strictly speaking, impossible. Further, it might be the case that, for the enlightened individual, the appropriate relationship with God is materially mediated in an extraordinary way through the everyday experience of God's creation, thus being neither direct nor immediate. Finally, as we discuss below, if embodied existence requires the individual to return from union with the divine to live an enlightened social existence in right relationship to God, 
such experiential union or annihilation might not itself represent the "ultimate fulfillment of human nature," even if it turns out to be a necessary component of such fulfillment.

3 From Seuses Leben (§LIII). In Seuse 1907, I9I (translation ALG).

4 Ibn 'Arabi, Al-Futūhāt al-Makkiyya II 6I9.I I, quoted in Chittick I989, I 55 .

5 From Seuses Leben (§LIII). In Seuse I907, I9I (trans. ALG).

6 See Hamburger I989. To explore these illustrations, see one of the earliest extant manuscripts of Suso's Exemplar (c. I370), available at http://gallica.bnf.fr/ark:/ I 2 4 48/btvibio224795t. (The illustration of the mystical journey can be found on fol. 82r.)

7 Yadav 20I6, I8. For a comparative discussion of practical apophaticism in Rumi and Eckhart, see also Zarrabi-Zadeh 2016.

8 See the famous hadith qudsi cited by many Sufi mystics: "I was a Hidden Treasure, so I loved to be known. Hence I created the creatures that I might be known" (quoted in Chittick I989, 39I, n.I4).

9 See https://digital.blb-karlsruhe.de/blbhs/content/pageview/I 234337.

Io Sarraj I960, 45 (trans. MSZ).

I I The three stages that progressively follow this station are known as the "journey with Truth in Truth," "the journey back to the world with Truth," and "the journey in the world with Truth" (see Nasr 2007, I28I29; Esposito 2004, 26).

I 2 For a discussion of the transformation of nafs in Sufi traditions, see Sviri 2002.

I3 See https://digital.blb-karlsruhe.de/blbhs/content/pageview/I 234326.

I4 See https://digital.blb-karlsruhe.de/blbhs/content/pageview/I 23434 I. For more on the philosophical and theological relevance of this mystical tradition, see Gebauer 2010; Griffioen 2017.

I 5 See the Eckhartian treatise On Detachment, in Meister Eckhart 2009, 566-574.

I6 From Büchlein der Wahrheit (§v), in Seuse I907, 340 (trans. ALG).

I7 See the response Suso receives from Eternal Wisdom concerning his self-mortification: "Until now you struck yourself with your own hands, had mercy on yourself [by] stopping when you wanted to. I want to give you over to [suffering] without any defenses." This passage is followed by Suso's vision of a dog tossing a foot-cloth from side to side and tearing it apart with its teeth. "So you shall be in your brothers' 
mouths," he reminds himself with an "inward sigh" (from Seuses Leben, §xx, in Seuse I907, $57 \mathrm{ff}$. [trans. ALG]).

I8 See Mechthild von Magdeburg 2010, I.44 (trans. ALG).

I9 Al-Qushayri, quoted in Sviri 2002, 205.

20 Hafez I983, 434-5 (trans. MSZ).

2 I See Seuses Leben (§IL), in Seuse I907, I68.

22 Seuses Leben (§XLIII), I45 (trans. ALG).

23 This chapter represents the output of a Collaborative International Research Grant from the American Academy of Religion for a project on "Longing, Suffering, and Love in Medieval Christian and Islamic Mysticism." We are very grateful to the AAR for its support, as well as to the countless scholars who commented on the various workshop and conference papers that gave rise to many of the ideas found herein. 


\section{References}

Awn, Peter J., 'The Ethical Concerns of Classical Sufism', Journal of Religious Ethics 11 (1983), 240-63.

Azadegan, Ebrahim, 'Deus Absconditus in Islamic Mysticism', Transcendent Philosophy: An International Journal for Comparative Philosophy and Mysticism 16 (2015), 195-212.

Banz, Romuald, Christus und die minnende Seele: Zwei spätmittelhochdeutsche mystische Gedichte, Germanische Abhandlungen, Vol. 29 (Bresgau: M. \&. H. Marcus, 1908).

Bruijn, Johannes T. P. de, Persian Sufi Poetry: An Introduction to the Mystical Use of Classical Persian Poems (Surrey, UK: Curzon Press, 1997).

Bynum, Caroline W., Fragmentation and Redemption: Essays on Gender and the Human Body in Medieval Religion (New York: Zone Books, 1994).

Chittick, William C., The Sufi Path of Knowledge: Ibn al-'Arabi's Metaphysics of Imagination (Albany, NY: SUNY Press, 1989).

Chittick, William C., 'Themes of Love in Islamic Mystical Theology' in S. T. Hidden (ed.), Jewish, Christian, and Islamic Mystical Perspectives on the Love of God (New York: Palgrave Macmillan US, 2014), pp. 155-80.

Dickens, Andrea J., The Female Mystic: Great Women Thinkers of the Middle Ages (London, New York: I.B. Tauris, 2009).

Esposito, John L., The Oxford Dictionary of Islam (Oxford: Oxford University Press, 2004).

Gebauer, Amy, 'Christus und die minnende Seele': An Analysis of Circulation, Text, and Iconography (Wiesbaden: Reichert, 2010).

Griffioen, Amber, 'Ich wird dich also an griffen / Das du mir nit mugist entwichen: Göttliche Aktivität, seelisches Leiden und die Rolle der Autonomie in Christus und die minnende Seele' in Benedikt Göcke and Ruben Schneider (eds.), Handelt Gott in der Welt?: Neue Ansätze aus Theologie und Religionsphilosophie. (Regensburg: Pustet Verlag, 2017), 41-72.

Haas, Alois M., Gottleiden - Gottlieben: Zur volkssprachlichen Mystik im Mittelalter (Frankfurt a. M.: Insel-Verlag, 1989).

Hafez, Shams al-Din Muhammad, Divan [Persian] (Tehran: Amirkabir Publishers, 1983).

Hamburger, Jeffrey F., 'The Use of Images in the Pastoral Care of Nuns: The Case of Heinrich Suso and the Dominicans', The Art Bulletin 71 (1989), 20-46.

Heck, Paul L., 'Mysticism as Morality', Journal of Religious Ethics 34 (2006), 253-86.

Hollywood, Amy, 'Introduction' in A. Hollywood and P. Z. Beckman (eds.), The Cambridge Companion to Christian Mysticism (Cambridge: Cambridge University Press, 2012), pp. 1-33.

John of the Cross, Dark Night of the Soul, trans. by E. Allison Peers (Image Books, 1994, 1959). Online at http://www.ccel.org/ccel/john_cross/dark_night.

Karamustafa, Ahmet T., 'Antinomian Sufis' in L. V. J. Ridgeon (ed.), The Cambridge Companion to Sufism (Cambridge: Cambridge University Press, 2015), pp. 101-24.

Kashani, Abd al-Razzaq, Lexicon of Sufi Terminology [Arabic] (Cairo, 1992).

Keller, Hildegard E., My Secret is Mine: Studies on Religion and Eros in the German Middle Ages (Leuven: Peeters, 2000). 
Lewisohn, Leonard, 'Sufism's Religion of Love, from Rabi'a to Ibn 'Arabi' in Lloyd Ridgeon (ed.), The Cambridge Companion to Sufism (Cambridge: Cambridge University Press, 2015), pp. 150-81.

McGinn, Bernard (ed.), Meister Eckhart and the Beguine Mystics: Hadewijch of Brabant, Mechthild of Magdeburg, and Marguerite Porete (New York: Continuum International Publishing, 1994).

McGinn, Bernard, The Mystical Thought of Meister Eckhart: The Man from Whom God Hid Nothing, (The Edward Cadbury Lectures) (New York: Crossroad Publishing, 2001).

Mechthild von Magdeburg, Das fließende Licht der Gottheit: Zweisprachige Ausgabe. Translated by Gisela Vollmann-Profe (Berlin: Verlag der Weltreligionen, 2010).

Meister Eckhart, The Complete Mystical Works of Meister Eckhart, translated by Maurice O'C Walshe (New York: Crossroad Publishing, 2009).

Nasr, Seyyed Hossein, The Garden of Truth: The Vision and Promise of Sufism, Islam's Mystical Tradition (New York: HarperOne, 2007).

Porete, Marguerite, The Mirror of Simple Souls. Translated by Ellen Babinsky (New York: Paulist Press, 1993).

Renard, John, The A to Z of Sufism (Lanham, MD: Scarecrow Press, 2009).

Rumi, Jalal ad-Din Muhammad, The Masnavi: Book One. Translated by Jawid Mojaddedi (Oxford: Oxford University Press, 2008).

Sarraj, Abu Nasr al, Flashes of Light [Arabic] (Cairo: Dar Al Kotob Al Haditha, 1960).

Sells, Michael, 'Ibn 'Arabi's Polished Mirror: Perspective Shift and Meaning Event', Studia Islamica (1988), 121-49.

Seuse, Heinrich, Heinrich Seuse: Deutsche Schriften, ed. by Karl Bihlmeyer (Stuttgart: W. Kohlhammer, 1907).

Sviri, Sara, 'The Self and Its Transformation in Sufism: With Special Reference to Early Literature' in David D. Shulman and Guy G. Stroumsa (eds.), Self and Self-Transformation in the History of Religions (Oxford: Oxford University Press, 2002), pp. 195-215.

Teresa of Avila, The Collected Works of St. Teresa of Avila, vol. 1. Translated by Kieran Kavanaugh and Otilio Rodriguez (Washington: ICS Publications, Institute of Carmelite Studies, 1976).

Van Dyke, Christina, 'Mysticism' in Robert Pasnau and Christina Van Dyke (eds.), The Cambridge History of Medieval Philosophy, vol. 2 (Cambridge: Cambridge University Press, 2010), pp. 720-34.

Van Dyke, Christina, 'Self-Knowledge, Abnegation, and Fulfillment in Medieval Mysticism' in Ursula Renz (ed.), Self-Knowledge: A History (Oxford: Oxford University Press, 2016), pp. 131-45.

Wittgenstein, Ludwig, Tractatus Logico-Philosophicus (London: Routledge, 2005).

Yadav, Sameer, 'Mystical Experience and the Apophatic Attitude', Journal of Analytic Theology 4 (2016), 17-43.

Zarrabi-Zadeh, Saeed, 'Comparative Mysticism and the Problem of Interpretation: Rumi and Meister Eckhart’, Islam and Christian-Muslim Relations 26 (2014), 287-306.

Zarrabi-Zadeh, Saeed, Practical Mysticism in Islam and Christianity: A Comparative Study of Jalal al-Din Rumi and Meister Eckhart (London: Routledge, 2016). 